\title{
Rekam Jejak Dosen Sebagai Model Pengambilan Keputusan Dalam Pemilihan Dosen Berprestasi
}

\author{
Safrizal \\ Instansi Jurusan Manajemen Informatika, STMIK Potensi Utama, Medan \\ E-mail: rizalsyl75@yahoo.co.id
}

\begin{abstract}
Abstrak
Sistem pendukung keputusan merupakan sistem informasi komputer yang digunakan oleh para pembuat keputusan untuk mendapatkan hasil keputusan terbaik dari beberapa alternatif keputusan sehingga memberikan hasil akhir yang tepat dan akurat. Salah satu metode pengambilan keputusan dalam situasi yang kompleks adalah dengan menggunakan metode Analytic Hierarchy Process (AHP). Di STMIK Potensi Utama rekam jejak dosen dilakukan setiap semester yang meliputi administrasi dosen, metode proses belajar mengajar, kegiatan dosen, penelitian dan pengabdian masyarakat yang dilaksanakan oleh dosen. Sulitnya menemukan dosen yang mempunyai prestasi pada rekam jejak tersebut, maka penulis melakukan penelitian dalam hal pemanfaatan rekam jejak dosen sebagai keputusan dalam pemilihan dosen berprestasi menggunakan metode AHP. Hasilnya adalah Administrasi Dosen (0.513 atau 51,3\%), Metode PBM (0.261 atau 26,1\%), Seminar/Kegiatan Dosen (0.063 atau 6,3\%), Penelitian (0.129 atau 12,9\%), Pengabdian Masyarakat (0.033 atau 3,3\%). Kriteria Administrasi Dosen merupakan kriteria terpenting diantara kriteria yang lain. Sedangkan hasil evaluasi rekam jejak dosen yang memiliki bobot prioritas yang paling tinggi dalam pemilihan dosen berprestasi adalah prioritas pertama dimiliki oleh Dosen A dengan bobot 0,349 atau 34,9\%, prioritas kedua dimiliki oleh Dosen A dengan nilai bobot 0,0337 atau 33,7\% dan Dosen B memiliki perioritas ketiga dengan nilai bobot nilai 0,314 atau 31,4\%.
\end{abstract}

Kata Kunci - DSS, rekam jejak, pemilihan dosen berprestasi, AHP

\begin{abstract}
Decision support system is an interactive information system used by the decision makers in order to obtain the best decision result among some other alternatives. One of the decision taking methods in complex situation is Analytic Hierarchy Process (AHP). At STMIK POTENSI UTAMA is done regularly every semester including lecture's administration learning teaching method, lecture's activities, research and social awareness done comprehensively by lecture's. However, it is difficult to find the lectures who have full filled those qualification, the written to write about a lecturer track record as model of decision taking in selecting lecturer performance by applying AHP Method. The finding are Lecture's Administration (0.513 or 51,3\%), PBM Method (0.261 or 26,1\%), seminary/lecture's Activities (0.063 or 6,3\%), Research (0.129 or $12,9 \%)$, and social awareness (0.033 or 3,3\%). It implies that lecture's administration criteria is the most important among others. While the evaluation of lecture's track recording that have high priority in lectures a with 0,349 or $34,9 \%$, the second priority goes on lectures A with 0,0337 or $33,7 \%$ and lectures $B$ is the third priority with 0,314 or $31,4 \%$.
\end{abstract}

Keywords - DSS, track recording, lecturer performance by applying, AHP 


\section{PENDAHULUAN}

Sistem pendukung keputusan merupakan suatu sistem informasi komputer interaktif yang dapat digunakan oleh para pembuat keputusan untuk mendapatkan hasil keputusan terbaik dari beberapa alternatif keputusan. Sistem ini memberikan hasil akhir yang tepat dan akurat karena berdasarkan pada data-data kualitatif yang telah diolah dengan menggunakan metode kuantitatif. Salah satu metode pengambilan keputusan dalam situasi yang kompleks adalah dengan menggunakan metode Analytic Hierarchy Process (AHP). AHP merupakan salah satu metode yang dapat digunakan dalam menentukan keputusan-keputusan yang akan diambil. Hasil akhir dari proses AHP adalah prioritas dari alternatif. Prioritas tersebut dapat digunakan untuk menentukan alternatif terbaik[1].

Dosen merupakan tenaga akademik yang bertugas melaksanakan tridarma perguruan tinggi, yang meliputi pendidikan dan pengajaran, penelitian dan pengembangan ipteks dan pengabdian pada masyarakat serta kegiatan penunjang. Pada dasarnya ketiga tugas tersebut wajib dilaksanakan secara terpadu oleh dosen. Pemilihan dosen berprestasi adalah memberikan pengakuan dosen secara nyata dan luar biasa melakukan kegiatan Tridharma Perguruan Tinggi yang hasilnya dapat dibanggakan dan sangat bermanfaat bagi kemajuan peningkatan kualitas akademik dan kelembagaan[2]. Evaluasi dosen merupakan cara untuk mengetahui pengaruh dan kulaitas pengajaran dosen terhadap mahasiswa[3]. Penilaian kinerja dosen dengan menggunakan AHP. Ada beberapa komponen didalam menilai kinerja dosen yaitu: Pengajaran, Penelitian, Pengabdian Masyarakat, Aktivitas Internal dan Penilaian Mahasiswa[4]. Sejalan dengan itu, proses rekam jejak dosen dilingkungan STMIK Potensi Utama dilakukan setiap semester yang meliputi administrasi dosen, metode proses belajar mengajar, kegiatan dosen, penelitian dan pengabdian kepada masyarakat yang dilaksanakan terpadu oleh dosen. Namun, sulit ditemukan dosen yang mempunyai prestasi pada rekam jejak tersebut. Berdasarkan hal tersebut penulis mengangkat permasalahan dalam hal pemanfaatan rekam jejak dosen sebagai keputusan dalam pemilihan dosen berprestasi dengan menggunakan metode AHP.

Tujuan penelitian ini adalah memanfaatan hasil rekam jejak dosen sebagai evaluasi kinerja dosen sehingga memberikan masukan kepada manajemen dalam menentukan dosen berprestasi yang sesuai dengan tri dharma perguruan tinggi yaitu dalam bidang pengajaran, penelitian dan pengabdian kepada masyarakat.

\section{METODE PENELITIAN}

Analisis Kebutuhan Alternatif dan Kriteria didapatkan dari hasil kuesioner dan wawancara dari atasan responden adalah sebagai berikut:

1. Data Alternatif

Data Dosen yang dijadikan sebagai penilaian dalam tridharma perguruan tinggi yaitu dalam bidang pengajaran, penelitian dan pengabdian kepada masyarakat.

2. Data Kriteria

Adapun Data Kriteria yang terdapat didalam rekam jejak dosen yang dijadikan sebagai dasar didalam pemilihan dosen berprestasi di STMIK Potensi Utama yaitu:

a. Administrasi Dosen meliputi kehadiran dosen, Ketpatan Waktu, Pengumpulan Nilai dan Pengumpulan Soal Ujian.

b. Metode PBM (Proses Belajar Mengajar) yang didapat dari penilaian mahasiswa yang disebarkan melalui kuesioner yang meliputi Ketepatan Waktu Kedatangan ke Kelas, Kesesuaian Penyampaian Materi dan Silabus, Penguasaan Materi Bahan Kuliah, Sistematika Penyampaian Materi Kuliah, Metode / Retorika Penyampaian, Penggunaan Alat Bantu Kuliah, Kemampuan Menjawab Pertanyaan, Sikap \& Prilaku Dosen, Kerapian Dosen, Kemampuan Memotivasi Mahasiswa, Kemampuan Menguasai Kelas, Kesempatan Bertanya dan Tranparansi Nilai. 
Citec Journal, Vol. 2, No. 1, November 2014 - Januari 2015

c. Kegiatan Dosen yang meliputi Seminar Ilmiah sesuai PS sebagai penyaji, Seminar Ilmiah sesuai PS sebagai peserta dan Seminar Ilmiah tidak sesuai PS (Penyaji/Peserta).

d. Bidang Penelitian meliputi Lokal, Nasional dan Internasional.

e. Bidang Pengabdian Kepada Masyarakat meliputi Lokal, Nasional dan Internasional.

Struktur hirarki dengan menggunakan metode Analytic Hierarchy Process (AHP) digunakan untuk pemilihan Dosen berprestasi. Struktur hirarki ditunjukkan pada Gambar 2.

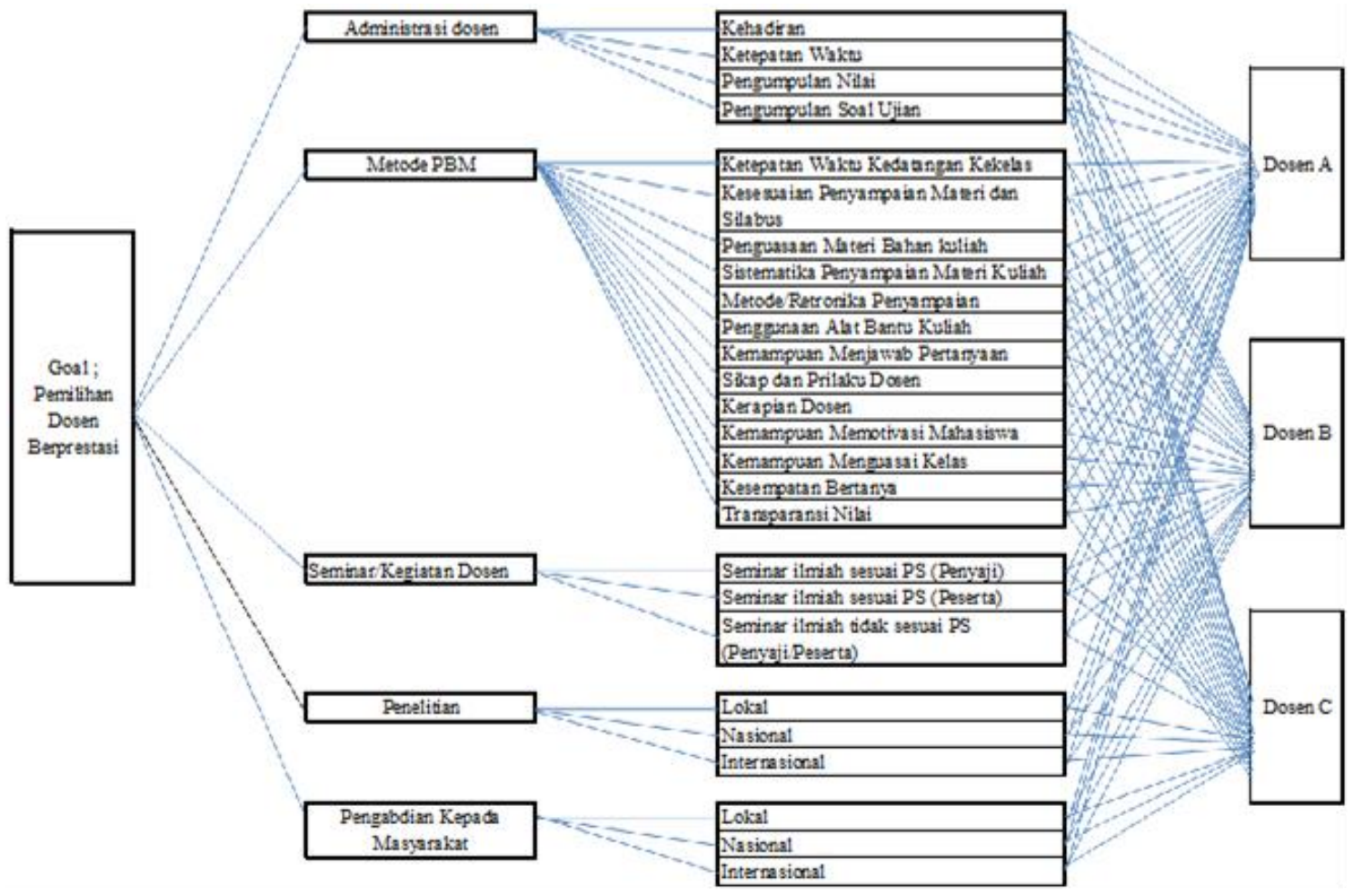

Gambar 1. Struktur Hirarki AHP

Analisis Kebutuhan Fungsional dari sistem pendukung keputusan terhadap Pemilihan Dosen Berprestasi di STMIK Potensi Utama adalah Sistem Memungkinkan untuk mendapatkan informasi alternatif -alternatif keputusan berupa Dosen yang terbaik dalam Administrasi, Metode Pengajaran, Kegiatan Dosen dalam mengikuti seminar ilmiah, penelitian dan pengabdian kepada masyarakat nantinya bisa menjadi bahan masukan terhadap pemilihan dosen berprestasi di lingkungan STMIK Potensi Utama.

\section{HASIL DAN PEMBAHASAN}

Berdasarkan hasil keputusan didalam proses pemilihan dosen berprestasi dilingkungan STMIK Potensi Utama maka peringkat kepentingan untuk semua kriteria di tujukan pada tabel 1.

Tabel 1. Peringkat Kepentingan untuk Semua Kriteria

\begin{tabular}{|c|l|c|}
\hline No & Kriteria & Nilai Kepentingan \\
\hline 1 & Administrasi Dosen & 5 \\
\hline 2 & Metode PBm & 4 \\
\hline 3 & Penelitian & 3 \\
\hline 4 & Seminar & 2 \\
\hline 5 & Pengabdian Kepada Masyarakat & 1 \\
\hline
\end{tabular}


Berdasarkan dari hasil peringkat kepentingan Perhitungan Faktor Pembobotan Hirarki untuk Semua Kriteria yang terdapat didalam rekam jejak dosen yang digunakan didalam pemilihan dosen berprestasi maka matriks perbandingan hasil preferensi berdasarkan Tabel 1 dapat ditunjukkan pada Tabel 2.

Tabel 2. Matriks Faktor Pembobotan Hirarki untuk Semua Kriteria

\begin{tabular}{|l|c|c|c|c|c|}
\hline \multicolumn{1}{|c|}{ Kriteria } & $\begin{array}{c}\text { Administrasi } \\
\text { Dosen }\end{array}$ & Metode PBM & $\begin{array}{c}\text { Seminar } \\
\text { Dosen }\end{array}$ & Penelitian & $\begin{array}{c}\text { Pengabdian kepada } \\
\text { Masyarakat }\end{array}$ \\
\hline Administrasi Dosen & 1 & 3 & 7 & 5 & 9 \\
\hline Metode PBM & $1 / 3$ & 1 & 5 & 3 & 7 \\
\hline Seminar Dosen & $1 / 7$ & $1 / 5$ & 1 & $1 / 3$ & 3 \\
\hline Penelitian & $1 / 5$ & $1 / 3$ & 3 & 1 & 5 \\
\hline Pengabdian kepada Masyarakat & $1 / 9$ & $1 / 7$ & $1 / 3$ & $1 / 5$ & 1 \\
\hline
\end{tabular}

Tabel 3. Matriks Faktor Pembobotan Hirarki untuk Semua Kriteria yang disederhanakan

\begin{tabular}{|c|c|c|c|c|c|}
\hline Kriteria & $\begin{array}{c}\text { Administrasi } \\
\text { Dosen }\end{array}$ & Metode PBM & $\begin{array}{c}\text { Seminar } \\
\text { Dosen }\end{array}$ & Penelitian & $\begin{array}{c}\text { Pengabdian kepada } \\
\text { Masyarakat }\end{array}$ \\
\hline Administrasi Dosen & 1,00 & 3,00 & 7,00 & 5,00 & 9,00 \\
\hline Metode PBM & 0,33 & 1,00 & 5,00 & 3,00 & 7,00 \\
\hline Seminar Dosen & 0,14 & 0,20 & 1,00 & 0,33 & 3,00 \\
\hline Penelitian & 0,20 & 0,33 & 3,00 & 1,00 & 5,00 \\
\hline Pengabdian kepada Masyarakat & 0,11 & 0,14 & 0,33 & 0,20 & 1,00 \\
\hline Total & 1,79 & 4,68 & 16,33 & 9,53 & 25,00 \\
\hline
\end{tabular}

Dengan unsur-unsur pada tiap kolom dibagi dengan jumlah kolom yang bersangkutan, akan diperoleh bobot relatif yang dinormalkan. Nilai vektor eigen dihasilkan dari rata-rata bobot relatif untuk setiap baris. Hasilnya dapat dilihat pada Tabel 4.

Tabel 4. Matriks Faktor Pembobotan Hirarki untuk Semua Kriteria yang Dinormalkan

\begin{tabular}{|l|c|c|c|c|c|c|}
\hline \multicolumn{1}{|c|}{ Kriteria } & $\begin{array}{c}\text { Administrasi } \\
\text { Dosen }\end{array}$ & Metode PBM & $\begin{array}{c}\text { Seminar } \\
\text { Dosen }\end{array}$ & Penelitian & $\begin{array}{c}\text { Pengabdian kepada } \\
\text { Masyarakat }\end{array}$ & $\begin{array}{c}\text { Vektor } \\
\text { Eigen }\end{array}$ \\
\hline Administrasi Dosen & 0,56 & 0,64 & 0,43 & 0,52 & 0,36 & 0,50 \\
\hline Metode PBM & 0,19 & 0,21 & 0,31 & 0,31 & 0,28 & 0,26 \\
\hline Seminar Dosen & 0,08 & 0,04 & 0,06 & 0,03 & 0,12 & 0,07 \\
\hline Penelitian & 0,11 & 0,07 & 0,18 & 0,10 & 0,20 & 0,13 \\
\hline Pengabdian kepada Masyarakat & 0,06 & 0,03 & 0,02 & 0,02 & 0,04 & 0,03 \\
\hline
\end{tabular}

Selanjutnya nilai eigen maksimum ( $\alpha$ maksimum) didapat dengan menjumlahkan hasil perkalian jumlah kolom dengan vektor eigen. Nilai eigen maksimum yang dapat diperoleh adalah:

$\alpha$ maksimum $=(1,79 * 0,50)+(4,68 * 0,26)+(16,33 * 0,07)+(9,53 * 0,13)+(25,00 * 0,03)$

$$
=5,37
$$

Karena matriks berordo 5 (yakni terdiri dari 5 kriteria), nilai indeks konsistensi yang diperoleh:

$$
C I=\frac{\alpha_{\max }-n}{n-1}=\frac{5,37-5}{5-1}=0,09
$$

Untuk n $=5, \mathrm{RI}=1,120$ (tabel Saaty), maka CR $=\frac{\mathrm{CI}}{\mathrm{RI}}=\frac{0,09}{1,120}=0,08<0,100$

Karena $\mathrm{CR}<0,100$ berarti preferensi responden adalah konsisten. 
Dari hasil perhitungan pada tabel 5 menunjukkan bahwa: kriteria Administrasi Dosen merupakan kriteria yang paling penting bagi pemilihan dosen berprestasi dengan bobot 0,50 atau $50 \%$, berikutnya adalah kriteria metode PBM dengan nilai bobot 0,26 atau $26 \%$, kemudian kriteria penelitian dengan nilai bobot 0,13 atau 13\%, kriteria Seminar Dosen dengan nilai bobot 0,07 atau $7 \%$ dan kriteria pengabdian masyarakat dengan nilai bobot 0,03 atau $3 \%$.

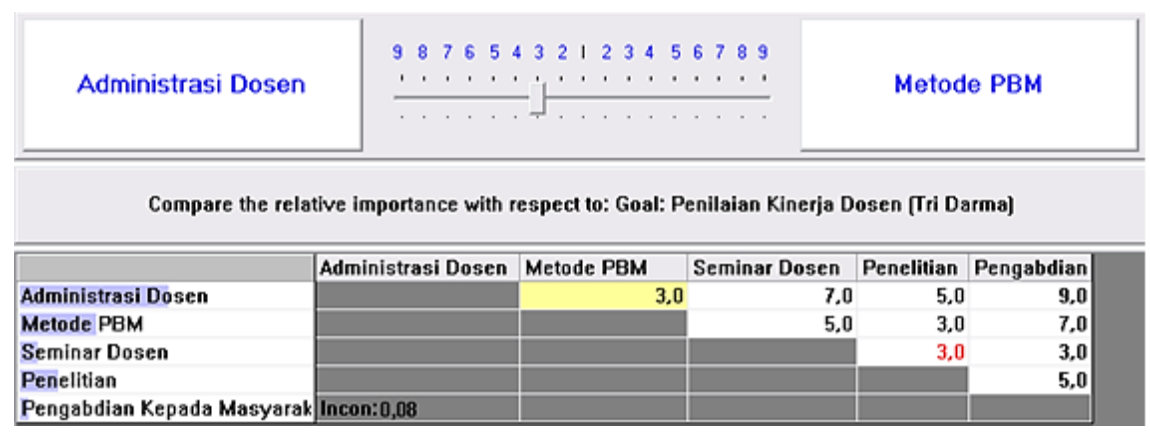

Gambar 2. Faktor Pembobotan Hirarki untuk Kriteria

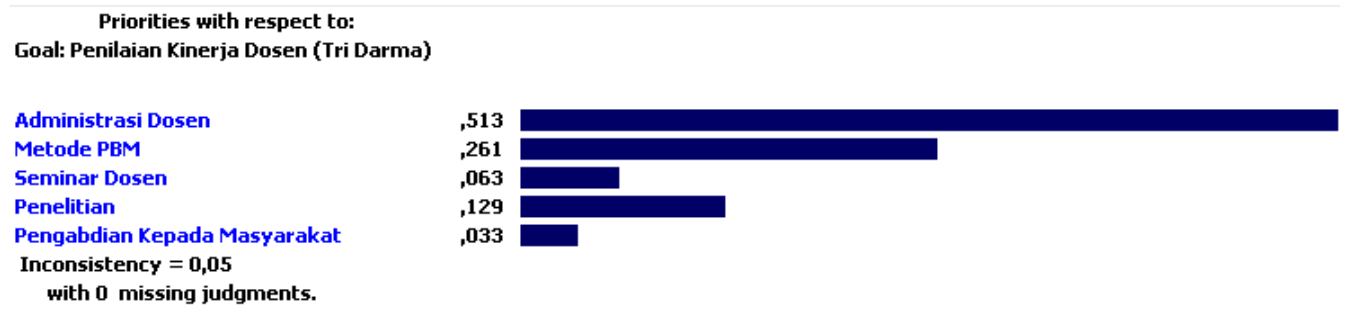

Gambar 3. Hasil Prioritas Terhadap Semua Kriteria

Standard Pemilihan Pernode dalam Cluster didapat berdasarkan hasil keputusan dalam proses pemilihan dosen berprestasi di lingkungan STMIK Potensi Utama, maka peringkat kepentingan untuk pernode dalam cluster sebagai berikut.

a. Administrasi Dosen

Tabel 5. Peringkat Kepentingan Node Dalam Cluster Administrasi Dosen

\begin{tabular}{|l|l|l|}
\hline No & Kriteria & Nilai Kepentingan \\
\hline 1 & Kehadiran & 4 \\
\hline 2 & Ketepatan Waktu & 3 \\
\hline 3 & Pengumpulan Nilai & 2 \\
\hline 4 & Pengumpulan Soal Ujian & 1 \\
\hline
\end{tabular}

Matriks perbandingan berpasangan pernode dalam cluster Administrasi Dosen dalam penilaian dosen berprestasi dapat dilihat pada Gambar 4 dan Gambar 5.

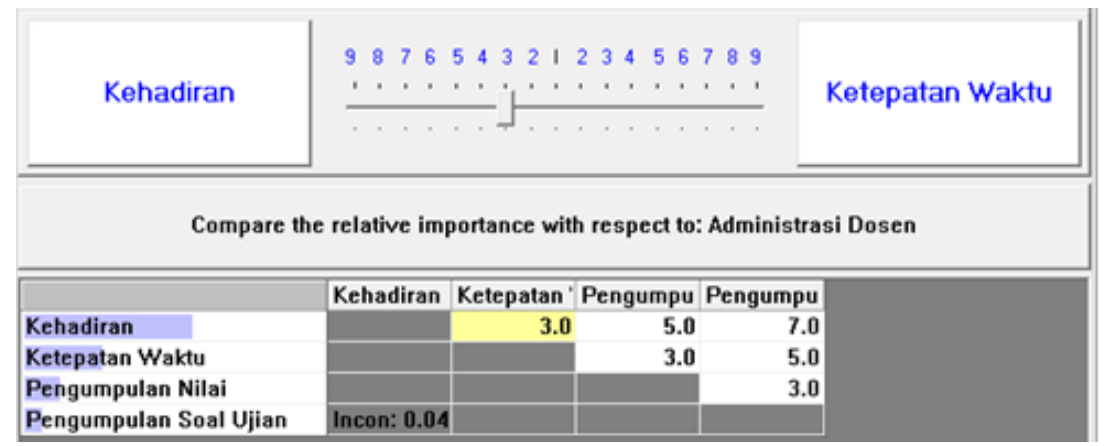

Gambar 4. Matrik Perbandingan Berpasangan Pernode Dalam Cluster Administrasi Dosen 

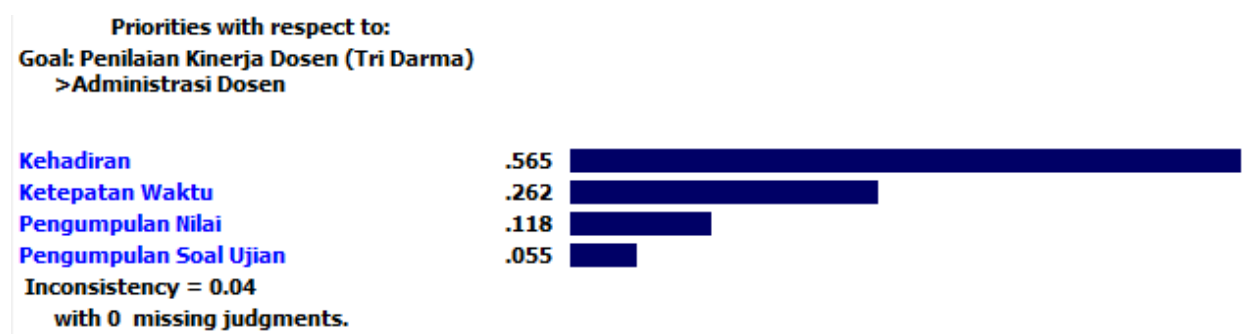

Gambar 5. Hasil Prioritas Pernode Dalam Cluster Administrasi Dosen

Dari hasil matriks perbandingan berpasangan pernode dalam cluster administrasi dosen pada gambar diatas maka diperoleh urutan prioritas yakni kehadiran merupakan node yang paling penting didalam cluster administrasi dosen dalam Pemilihan dosen berprestasi dengan bobot 0,565 atau $56 \%$, ketepatan waktu dengan bobot 0,262 atau $26 \%$, pengumpulan nilai dengan bobot 0,118 atau $11 \%$ dan pengumpulan soal ujian dengan bobot 0,055 atau $5 \%$.

b. Metode PBM

Tabel 6. Peringkat Kepentingan Node Dalam Cluster Metode PBM

\begin{tabular}{|l|l|c|}
\hline No & Kriteria & Nilai Kepentingan \\
\hline 1 & Ketepatan Waktu Kedatangan Kekelas & 9 \\
\hline 2 & Kesesuaian Penyampaian Materi dan Silabus & 8 \\
\hline 3 & Penguasaan Materi Bahan kuliah & 7 \\
\hline 4 & Sistematika Penyampaian Materi Kuliah & 6 \\
\hline 5 & Metode/Retronika Penyampaian & 5 \\
\hline 6 & Penggunaan Alat Bantu Kuliah & 5 \\
\hline 7 & Kemampuan Menjawab Pertanyaan & 4 \\
\hline 8 & Sikap dan Prilaku Dosen & 3 \\
\hline 9 & Kerapian Dosen & 3 \\
\hline 10 & Kemampuan Memotivasi Mahasiswa & 2 \\
\hline 11 & Kemampuan Menguasai Kelas & 2 \\
\hline 12 & Kesempatan Bertanya & 2 \\
\hline 13 & Transparansi Nilai & 1 \\
\hline
\end{tabular}

Matriks perbandingan berpasangan pernode dalam cluster metode PBM dalam penilaian dosen berprestasi dapat dilihat pada Gambar 6 dan Gambar 7 .

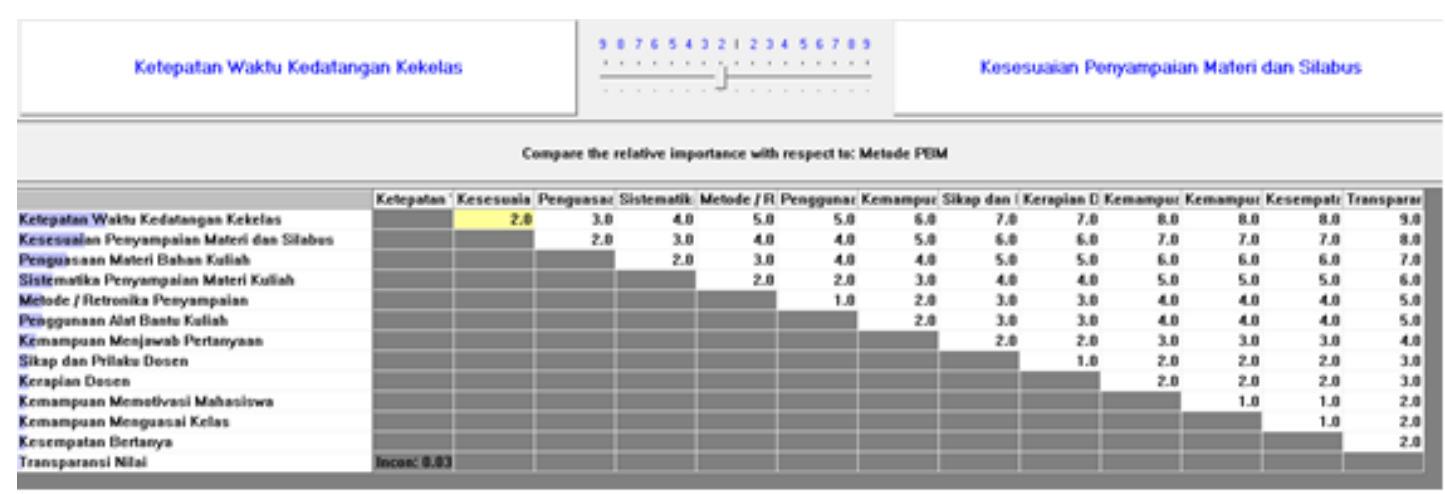

Gambar 6. Matrik Perbandingan Berpasangan Pernode Dalam Cluster Metode PBM 

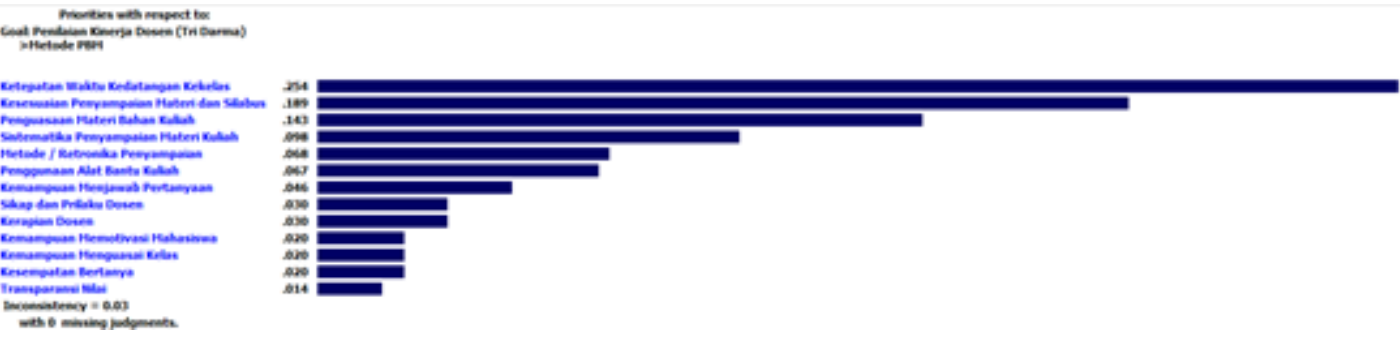

Gambar 7. Hasil Prioritas Pernode Dalam Cluster Metode PBM

Dari hasil matriks perbandingan berpasangan pernode dalam cluster metode PBM pada gambar diatas maka diperoleh urutan prioritas yakni ketepatan waktu kedatangan kekelas merupakan node yang paling penting didalam cluster metode PBM dalam Pemilihan dosen berprestasi dengan bobot 0,254 atau $25 \%$, kesesuaian penyampaian materi dan silabus dengan bobot 0,189 atau 18\%, penguasaan materi bahan kuliah dengan bobot 0,143 atau 14\%, sistematika penyampaian materi kuliah dengan bobot 0,098 atau $9 \%$, metode/retronika penyampaian dengan bobot 0,068 atau $6,8 \%$, penggunaan alat bantu kuliah dengan bobot 0,067 atau $6,7 \%$, kemampuan menjawab pertanyaan dengan bobot 0,046 atau 4,6\%, sikap prilaku emdosen dan kerapian dosen dengan bobot 0,030 atau 3\%, kemampuan memotivasi mahasiswa, kemampuan menguasai kelas dan kesempatan bertanya memiliki bobot yang sama yaitu 0,020 atau 2\% dan transparansi nilai dengan bobot 0,014 atau 1,4\%.

c. Seminar/Kegiatan Dosen

Tabel 7. Peringkat Kepentingan Node Dalam Cluster Seminar/Kegiatan Dosen

\begin{tabular}{|l|l|c|}
\hline No & Kriteria & Nilai Kepentingan \\
\hline 1 & Seminar ilmiah sesuai PS (Penyaji) & 3 \\
\hline 2 & Seminar ilmiah sesuai PS (Peserta) & 2 \\
\hline 3 & Seminar ilmiah tidak sesuai PS (Penyaji/Peserta) & 1 \\
\hline
\end{tabular}

Matriks perbandingan berpasangan pernode dalam cluster seminar/kegiatan dosen dalam penilaian dosen berprestasi dapat dilihat pada Gambar 8 dan Gambar 9.

\begin{tabular}{|c|c|c|c|}
\hline $\begin{array}{c}\text { Seminar IImiah } \\
\text { Sesuai PS (Penyaji) }\end{array}$ & 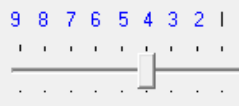 & $\begin{array}{llllllll}2 & 3 & 4 & 5 & 6 & 7 & 8 & 9 \\
1 & 1 & 1 & 1 & 1 & 1 & 1 & 1 \\
& . & . & . & . & . & . & \end{array}$ & $\begin{array}{c}\text { Seminar Ilmiah } \\
\text { Sesuai PS } \\
\text { (Peserta) }\end{array}$ \\
\hline \multicolumn{4}{|c|}{ Compare the relative importance with respect to: Seminar Dosen } \\
\hline & & Seminar IIr Semir & Seminar IIr \\
\hline \multicolumn{2}{|c|}{ Seminar IImiah Sesuai PS [Penyaji] } & & 8.0 \\
\hline \multicolumn{2}{|c|}{ Seminar Ilmiah Sesuai PS [Peserta] } & & 4.0 \\
\hline \multicolumn{2}{|c|}{ Seminar IImiah Tidak Sesuai PS [Penyaji/Peserta) } & Incon: 0.05 & \\
\hline
\end{tabular}

Gambar 8. Matrik Perbandingan Berpasangan Pernode Dalam Cluster Seminar/Kegiatan Dosen

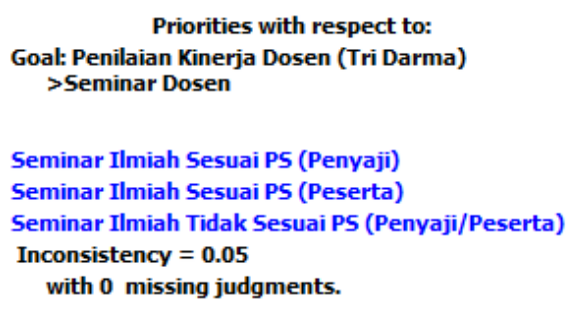

Gambar 9. Hasil Prioritas Pernode Dalam Cluster Seminar/Kegiatan Dosen 
Dari hasil matriks perbandingan berpasangan pernode dalam cluster seminar/kegiatan dosen pada gambar di atas maka diperoleh urutan prioritas yakni seminar ilmiah sesuai PS (penyaji) merupakan node yang paling penting didalam cluster seminar/kegiatan dosen dalam Pemilihan dosen berprestasi dengan bobot 0,707 atau $70 \%$, seminar ilmiah sesuai PS (peserta) dengan bobot 0,223 atau $22 \%$, dan seminar ilmiah tidak sesuai PS (penyaji/peserta) dengan bobot 0,070 atau $7 \%$.

d. Penelitian

Tabel 8. Peringkat Kepentingan Node Dalam Cluster Penelitian

\begin{tabular}{|l|l|l|}
\hline No & Kriteria & Nilai Kepentingan \\
\hline 1 & Lokal & 3 \\
\hline 2 & Nasional & 2 \\
\hline 3 & Internasional & 1 \\
\hline
\end{tabular}

Matriks perbandingan berpasangan pernode dalam cluster penelitian dalam penilaian dosen berprestasi dapat dilihat pada Gambar 10 dan Gambar 11.

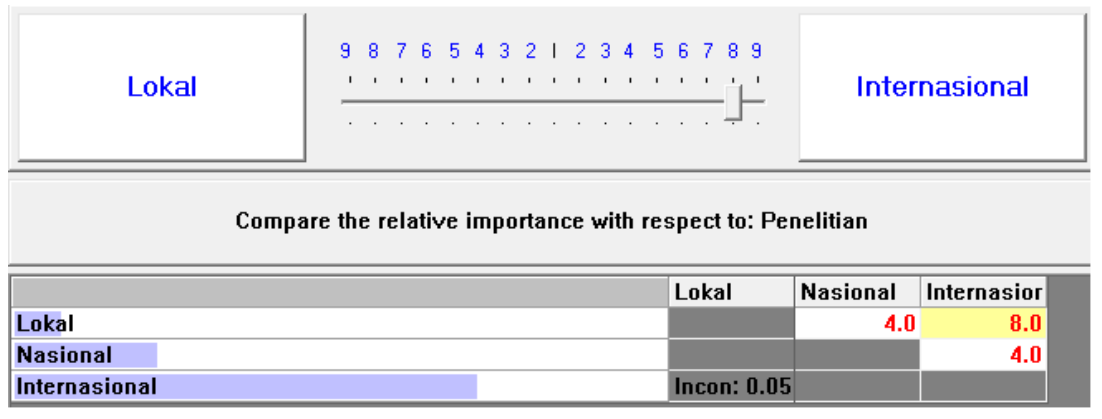

Gambar 10. Matrik Perbandingan Berpasangan Pernode Dalam Cluster Penelitian
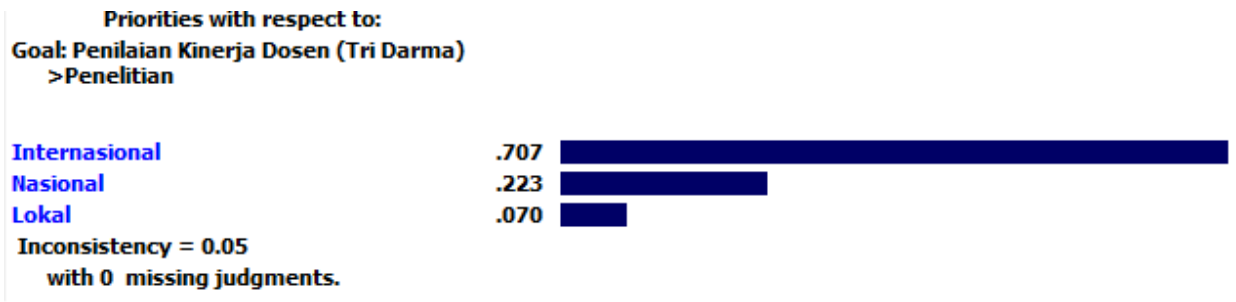

Gambar 11. Hasil Prioritas Pernode Dalam Cluster Penelitian

Dari hasil matriks perbandingan berpasangan pernode dalam cluster penelitian pada gambar diatas maka diperoleh urutan prioritas yakni internasional merupakan node yang paling penting didalam cluster penelitian dalam Pemilihan dosen berprestasi dengan bobot 0,707 atau $70 \%$, nasional dengan bobot 0,223 atau $22 \%$, dan lokal dengan bobot 0,070 atau $7 \%$

e. Pengabdian Kepada Masyarakat

Tabel 9. Peringkat kepentingan node dalam cluster Penelitian

\begin{tabular}{|l|l|c|}
\hline No & Kriteria & Nilai Kepentingan \\
\hline 1 & Lokal & 3 \\
\hline 2 & Nasional & 2 \\
\hline 3 & Internasional & 1 \\
\hline
\end{tabular}


Matriks perbandingan berpasangan pernode dalam cluster pengabdian kepada masyarakat dalam penilaian dosen berprestasi dapat dilihat pada Gambar 11 dan Gambar 12.

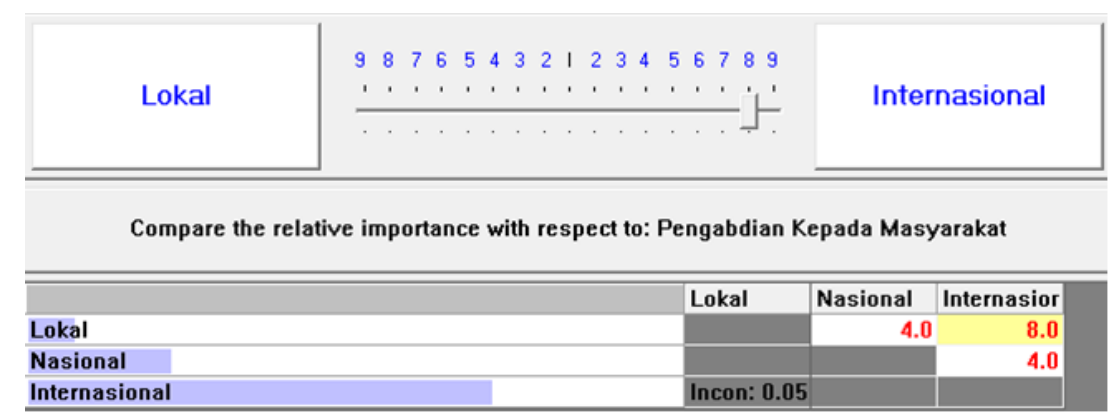

Gambar 11. Matrik perbandingan berpasangan pernode dalam cluster pengabdian kepada masyarakat
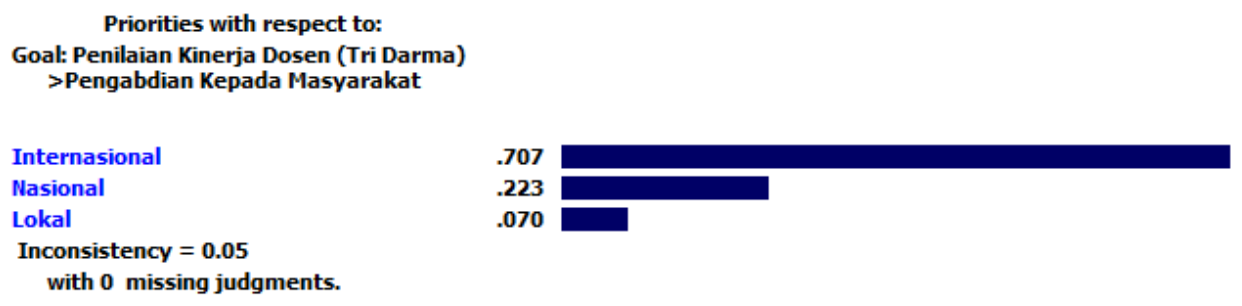

Gambar 12. Hasil Prioritas pernode dalam cluster pengabdian kepada masyarakat

Dari hasil matriks perbandingan berpasangan pernode dalam cluster pengabdian kepada masyarakat pada gambar diatas maka diperoleh urutan prioritas yakni internasional merupakan node yang paling penting didalam cluster pengabdian kepada masyarakat dalam Pemilihan dosen berprestasi dengan bobot 0,707 atau $70 \%$, nasional dengan bobot 0,223 atau $22 \%$, dan lokal dengan bobot 0,070 atau $7 \%$.

Analisis Bobot antara Kriteria dengan Alternatif, Setelah dihitung bobot prioritas dari setiap criteria dan sub kriteria, untuk selanjutnya menghitung bobot prioritas untuk setiap alternatif kepada sub kriteria yang ada. Alternatif dosen untuk masalah pemilihan dosen berprestasi berdasarkan rekam jejak dosen yaitu dalam bidang tridharma perguruan tinggi meliputi Administrasi Dosen, Metode PBM, Seminar/kegiatan dosen, penelitian dan pengabdian kepada masyarakat. Dari pemanfaatan rekam jejak tersebut dicari dosen yang memiliki prestasi yang baik sesuai dengan nilai bobot yang akan diperbandingkan terhadap setiap sub kriteria. Pada analisis ini sama halnya dengan analisis matriks perbandingan kriteria dan sub kriteria, nilai bobot prioritas yang paling besar maka alternatif tersebut menjadi pilihan utama yang terpenting dari sub kriteria. Pada tabel 10 adalah tabel dari rekapitulasi bobot prioritas alternatif. 
Tabel 10. Bobot Prioritas Global Tingkat Alternatif (AHP)

\begin{tabular}{|c|c|c|c|c|c|c|}
\hline Kriteria & Bobot & Sub Kriteria & Bobot & $\begin{array}{c}\text { Dosen } \\
\text { A }\end{array}$ & $\begin{array}{c}\text { Dosen } \\
\text { B }\end{array}$ & $\begin{array}{l}\text { Dosen } \\
\text { C }\end{array}$ \\
\hline \multirow{4}{*}{ Administrasi dosen } & \multirow{4}{*}{0.513} & Kehadiran & 0.565 & 0.333 & 0.333 & 0.333 \\
\hline & & Ketepatan Waktu & 0.262 & 0.333 & 0.333 & 0.333 \\
\hline & & Pengumpulan Nilai & 0.118 & 0.111 & 0.111 & 0.778 \\
\hline & & Pengumpulan Soal Ujian & 0.055 & 0.067 & 0.467 & 0.467 \\
\hline \multirow{13}{*}{ Metode PBM } & \multirow{13}{*}{0.261} & $\begin{array}{l}\text { Ketepatan Waktu Kedatangan } \\
\text { Kekelas }\end{array}$ & 0.254 & 0.637 & 0.105 & 0.258 \\
\hline & & $\begin{array}{l}\text { Kesesuaian Penyampaian } \\
\text { Materi dan Silabus }\end{array}$ & 0.189 & 0.637 & 0.105 & 0.258 \\
\hline & & $\begin{array}{l}\text { Penguasaan Materi Bahan } \\
\text { kuliah }\end{array}$ & 0.143 & 0.429 & 0.429 & 0.143 \\
\hline & & $\begin{array}{l}\text { Sistematika Penyampaian } \\
\text { Materi Kuliah }\end{array}$ & 0.098 & 0.429 & 0.143 & 0.429 \\
\hline & & $\begin{array}{l}\text { Metode/Retronika } \\
\text { Penyampaian }\end{array}$ & 0.068 & 0.429 & 0.143 & 0.429 \\
\hline & & Penggunaan Alat Bantu Kuliah & 0.067 & 0.143 & 0.143 & 0.714 \\
\hline & & $\begin{array}{l}\text { Kemampuan Menjawab } \\
\text { Pertanyaan }\end{array}$ & 0.046 & 0.333 & 0.333 & 0.333 \\
\hline & & Sikap dan Prilaku Dosen & 0.030 & 0.200 & 0.200 & 0.600 \\
\hline & & Kerapian Dosen & 0.030 & 0.091 & 0.455 & 0.455 \\
\hline & & $\begin{array}{l}\text { Kemampuan Memotivasi } \\
\text { Mahasiswa }\end{array}$ & 0.020 & 0.600 & 0.200 & 0.200 \\
\hline & & Kemampuan Menguasai Kelas & 0.020 & 0.200 & 0.600 & 0.200 \\
\hline & & Kesempatan Bertanya & 0.020 & 0.333 & 0.333 & 0.333 \\
\hline & & Transparansi Nilai & 0.014 & 0.143 & 0.429 & 0.429 \\
\hline \multirow{3}{*}{$\begin{array}{l}\text { Seminar/ Kegiatan } \\
\text { Dosen }\end{array}$} & \multirow{3}{*}{0.063} & $\begin{array}{l}\text { Seminar ilmiah sesuai PS } \\
\text { (Penyaji) }\end{array}$ & 0.707 & 0.122 & 0.648 & 0.230 \\
\hline & & $\begin{array}{l}\text { Seminar ilmiah sesuai PS } \\
\text { (Peserta) }\end{array}$ & 0.223 & 0.230 & 0.122 & 0.648 \\
\hline & & $\begin{array}{l}\text { Seminar ilmiah tidak sesuai PS } \\
\text { (Penyaji/Peserta) }\end{array}$ & 0.070 & 0.260 & 0.327 & 0.413 \\
\hline \multirow{3}{*}{ Penelitian } & \multirow{3}{*}{0.129} & Lokal & 0.070 & 0.286 & 0.143 & 0.571 \\
\hline & & Nasional & 0.223 & 0.333 & 0.333 & 0.333 \\
\hline & & Internasional & 0.707 & 0.333 & 0.333 & 0.333 \\
\hline \multirow{3}{*}{$\begin{array}{l}\text { Pengabdian } \\
\text { Kepada } \\
\text { Masyarakat }\end{array}$} & \multirow{3}{*}{0.033} & Lokal & 0.070 & 0.250 & 0.500 & 0.250 \\
\hline & & Nasional & 0.223 & 0.333 & 0.333 & 0.333 \\
\hline & & Internasional & 0.707 & 0.333 & 0.333 & 0.333 \\
\hline \multicolumn{3}{|c|}{ Bobot Perioritas } & 1 & 0.337 & 0.314 & 0.349 \\
\hline
\end{tabular}

Berdasarkan hasil pengolahan data di atas masing-masing bobot kriteria sebagai berikut: Administrasi Dosen (0.513 atau 51,3\%), Metode PBM (0.261 atau 26,1\%), Seminar/Kegiatan Dosen (0.063 atau 6,3\%), Penelitian (0.129 atau 12,9\%), dan Pengabdian Kepada Masyarakat (0.033 atau 3,3\%). Hal ini mengandung arti bahwa kriteria Administrasi Dosen merupakan kriteria yang terpenting diantara kriteria yang lain. Sedangkan hasil evaluasi rekam jejak dosen yang memiliki bobot prioritas yang paling tinggi dalam pemilihan dosen berprestasi adalah prioritas pertama dimiliki oleh Dosen A dengan bobot 0,349 atau 34,9\%, prioritas kedua dimiliki oleh Dosen A dengan nilai bobot 0,0337 atau 33,7\% dan Dosen B memiliki perioritas ketiga dengan nilai bobot nilai 0,314 atau $31,4 \%$. 
Citec Journal, Vol. 2, No. 1, November 2014 - Januari 2015
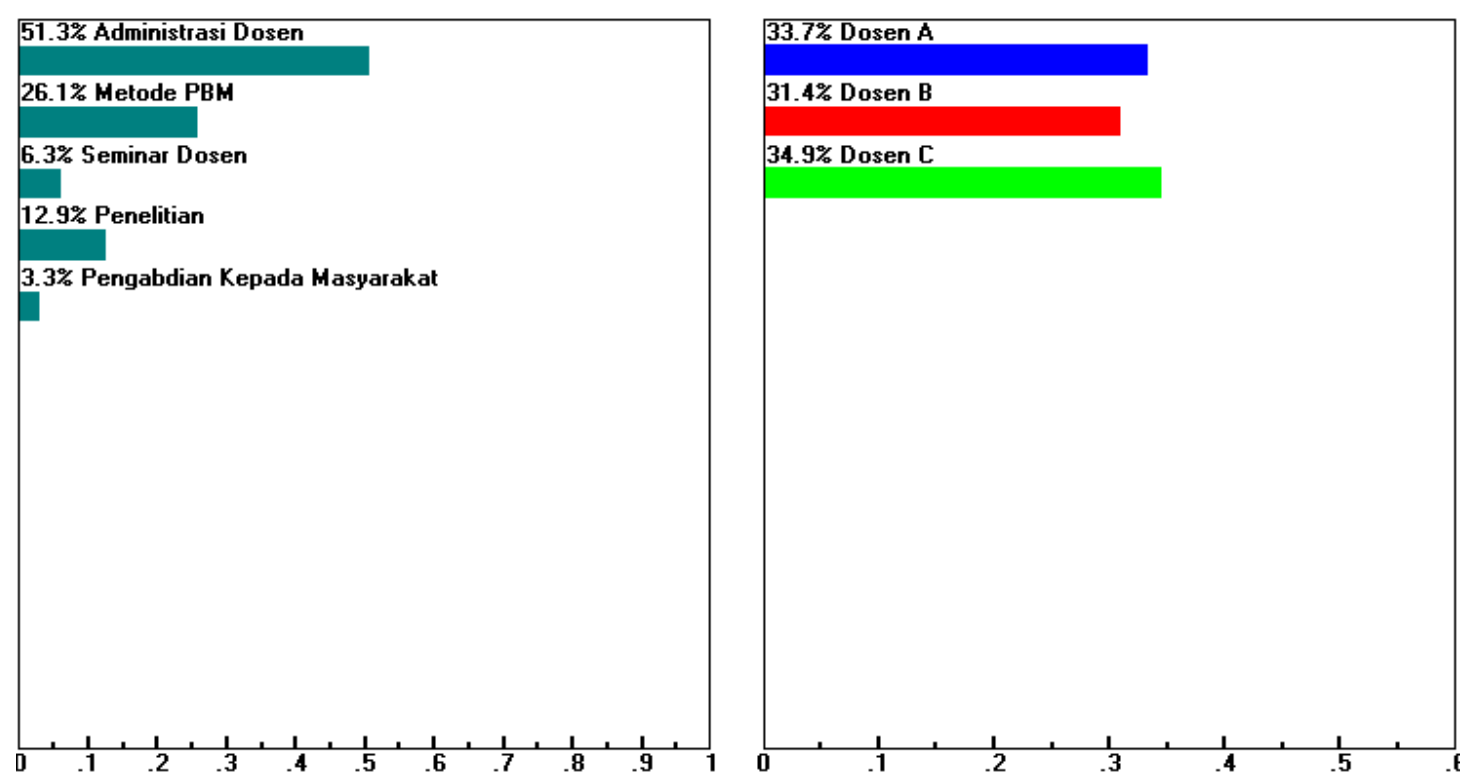

Gambar 13. Hasil Prioritas pemilihan dosen berprestasi berdasarkan rekam jejak dosen

Hasil Pengujian didapat dari hasil perhitungan data sampel dalam memilih dosen berprestasi berdasarkan rekam jejak dosen dapat dilihat pada tabel 11.

Tabel 11. Bobot Final dan Ranking Alternatif

\begin{tabular}{|l|l|l|l|l|}
\hline No & Alternatif & $\begin{array}{l}\text { Pengujian } \\
\text { Software }\end{array}$ & $\begin{array}{l}\text { Pengujian } \\
\text { Manual }\end{array}$ & Ranking \\
\hline 1 & Dosen C & $34,9 \%$ & $35 \%$ & 1 \\
\hline 2 & Dosen A & $33,7 \%$ & $33 \%$ & 2 \\
\hline 3 & Dosen B & $31,4 \%$ & $32 \%$ & 3 \\
\hline
\end{tabular}

Dari hasil perbandingan, didapatkan hasil akurasi manual dan dengan software terendah $88 \%$ dan akurasi tertinggi $100 \%$. Dari hasil pengujian baik dengan manual ataupun software dapat dihasilkan ranking yang layak untuk mendapatkan pemilihan dosen berprestasi sesuai dengan rekam jejak dosen di lingkungan STMIK Potensi Utama.

\section{KESIMPULAN}

1. Rekam jejak dosen sebagai model dalam pengambilan keputusan untuk pemilihan dosen berprestasi dengan metode Analytic Hierarchy Process (AHP). Metode AHP digunakan karena sesuai dengan kondisi perusahaan dimana terdapat keterkaitan antar subkriteria. Berdasarkan hasil pengolahan data dengan menggunakan metode AHP maka diperoleh hasil yaitu hasil evaluasi rekam jejak dosen yang memiliki bobot prioritas yang paling tinggi dalam pemilihan dosen berprestasi adalah prioritas pertama dimiliki oleh Dosen A dengan bobot 0,349 atau 34,9\%, prioritas kedua dimiliki oleh Dosen A dengan nilai bobot 0,0337 atau $33,7 \%$ dan Dosen B memiliki perioritas ketiga dengan nilai bobot nilai 0,314 atau 31,4\%.

2. Dengan menggunakan sebuah sistem maka akan lebih mudah menentukan keputusan manajemen dalam pemilihan dosen berprestasi dilingkungan STMIK Potensi Utama. 


\section{SARAN}

1. Penelitian dapat dijadikan sebagai acuan dalam pemilihan dosen berprestasi pada Intansi perguruan tinggi lainnya

2. Penelitian ini dapat dikembangkan untuk menyelesaikan masalah bagaimana menentukan dosen berprestasi sesuai dengan tridharma perguruan tinggi.

3. Penelitan ini dapat dikembangkan lebih lanjut dengan penajaman dan penambahan pada atribut faktor, elemen juga alternatif.

4. Perlu adanya dukungan dari berbagai pihak yang terkait, supaya sistem dapat berjalan dengan baik dan memberikan hasil yang dapat membantu membuat keputusan oleh pihak manajemen.

\section{DAFTAR PUSTAKA}

[1] Saaty, T. L., Peniwati, K., 2008, Group Decision Making: Drawing Out and Reconcilling Differences, RWS Publications, Pittsburgh.

[2] Eniyati, S., Santi, R. C. N., 2010, Perancangan Sistem Pendukung Keputusan Penilaian Prestasi Dosen Berdasarkan Penelitian dan Pengabdian Masyarakat, Jurnal Teknologi Informasi DINAMIK, Vol. XV, No. 2, Hal 136-142.

[3] Ramsden, P., 2003, Learning to Teach in Higher Education, $2^{\text {nd }}$ Ed, Routledge, London \& New York.

[4] Sestri, E., 2013, Penilaian Kinerja Dosen dengan Menggunakan Metode AHP, Jurnal Liquidity, Vol. 2, No. 1, Hal 100-109. 